\title{
Yumi Yi*
}

\section{Establishing the concept of AI literacy: Focusing on competence and purpose}

\begin{abstract}
SUMMARY
This study aimed to examine the concept, competence, and educational goals of artificial intelligence (AI) literacy to explore the basic competencies required for life in the AI era. Modern society is foreshadowing a new world, unlike the previous framework. Beyond the ability to read and write, literacy now also implies the ability to network and contact wider circles with greater information. In education, the learner's frame has gained greater importance than the teacher's frame. AI is playing a central role in making these changes. Like writing, AI has entered the system of everyday life and become a target of basic literacy. This study explored the concept and characteristics of AI literacy. AI contributes to enhancing human abilities by expanding human relationships and the scope of information acquisition. However, these characteristics of AI require humans to independently choose what humans need to know and whom to connect with. Knowing what to know is metacognition. Therefore, this study considered metacognition as competence in AI literacy. In addition, attempting to acquire more accurate knowledge through metacognition involves an effort to anticipate an uncertain future. Thus, the purpose of AI literacy is to have anticipation capabilities.
\end{abstract}

Keywords: literacy, AI literacy, AI literacy competence, AI literacy purpose, metacognition, anticipation.

\section{Introduction}

"One cannot not communicate" (Watzlawick, Bavelas \& Jackson, 2011, p. 30) is an important sentence that describes humans, focusing on the human instinct to communicate and viewing people as subjects of communication. Humans have always attempted to communicate, particularly when meeting others. As writing * Correspondence Address: Yumi Yi, Humanities Research Institute, Chung-Ang University, Dongjak-gu, Seoul
06974, Korea. E-mail: joystu@cau.ac.kr. ORCID: https://orcid.org/0000-0002-1230-041X. 
developed to enhance the accuracy and scalability of communication, it strengthened the power of information. Acquiring the ability to write has become important for acquiring information.

This relates to literacy. The word literacy is derived from the Latin root word, littera, meaning the ability to read and write letters. It is important to education, as it is related to the inequality of opportunities for social participation at individual and social levels among adults and children (Kagitcibasi, Goksen \& Gulgoz, 2005; Nichols, 2007). In terms of the basic communication education needed to ensure social equality, the subject of literacy has expanded in various ways, such as the ability to use communication media suitable for the times. Various forms of literacy have emerged, such as visual, digital, and technological literacy. Modern society is an age of artificial intelligence (AI). Although individuals may not be aware of it, AI technology is incorporated into many aspects of life.

Just as traditional literacy skills have been associated with individual rights, understanding $\mathrm{AI}$ is essential in the $\mathrm{AI}$ era. Therefore, this study aimed to define $\mathrm{AI}$ literacy and to consider the competence and purpose of AI literacy.

\section{Changes in the concept of literacy}

If literacy was based on a technical understanding of symbols for communication, it should have started with the development of ancient hieroglyphs and numbers. Some archaeologists have mentioned that the notation of numbers marked the origin of graphic representation (d'Errico, 1989, 2001; Marshack, 1964, 1972, as cited in Chrisomalis, 2009). Language literacy, the most basic of literacy research, has been an important object in school education for over 500 years since typography was developed by Gutenberg in 1492 (Hall, 1987; Holdaway, 1984). Language literacy refers to the ability to read and write letters. In literacy theory, the fundamental literacy competence is 3 Rs. 3Rs is Reading wRiting, aRithmetic. In this paper, 3Rs are defined as functional literacy.

Visual communication began with Edison's first film in the 1890s, but visual literacy has not been included in the curriculum in school education. Visual literacy was clarified by Debes $(1968,1969)$ and was specifically developed by Bradent and Hortin (1982). The broadcasting system created the concept of television literacy (Johnson, 1977; Salomon, 1982), and the spread of computers gave birth to computer literacy (Horton, 1983; Luehrmann \& Peckham, 1983, as cited in Hahn, 2020). Consequently, information and communication technology (ICT) has transformed and necessitated digital literacy. Gilster (1997) defined digital literacy as not simply the ability to use computers but a critical thinking ability to properly understand 
the value of information found on the Internet and use it properly by understanding and combining information suitable for one's purpose. He argues that the ability to evaluate and judge digitized information and combine it with new information to suit one's purpose is important; therefore, information found on the Internet must be understood and verified through critical evaluation.

Not only the development of media but also the educational purpose of each era influenced the change in literacy theories. A new perspective argued that literacy should consider social phenomena instead of merely focusing on literal education. Barton mentions (2001) that this constitutes the New Literacy Studies, developed by Gee (1990) and enhanced by scholars such as Street (1998) and Lankshear and Knobel (2007). New Literacy regards the social practice as an important purpose of literacy. Therefore, critical thinking is performed through literacy, meaning that literacy is not simply a functional dimension but a component of social participation (Street, 2003). Social participation means becoming more socially connected through literacy. This is related to extending the literacy event mentioned in Heath (1982) to literacy practices by linking them with social practices. This extension marked an attempt to connect literacy more widely in cultural and social terms (Burnett \& Merchant, 2002). Literacy began to be discussed by researchers in New Literacy Studies, with critical thinking being viewed as a core competency. Researchers in new literacy studies claimed that symbols, which constitute text systems, serve as a tool for strategic communication beyond the simple transmission of information and that through critical understanding, subjectivity can be acquired as a member of society. This claim is meaningful in that it has expanded the realm of literacy to the social level (Gee, 2005).

The New London Group (1996) devised the principles of situated practice, overt instruction, critical framing, and transformed practice as a literacy education method by establishing the concept of multiliteracy. Situated practice refers to a context where a student has the experience of designing meaning in a public space, such as a personal life scene or workplace. Overt instruction refers to facilitating the systematic, analytical, and conscious understanding of semantic design and its process. Critical framing enables the individual to interpret semantic design in a socio-cultural context and gain a critical perspective. Transformed practice enables them to have the experience of transforming the constructed meaning into another form in a different context or cultural phase. These four educational principles guide instructors in providing learners with valuable experiences around meaning construction in practical contexts and explicitly instruct learners to accurately understand the process, induce critical recognition of meaning construction, and experience various media transformations. New technology in multiliteracy is similar to a new language, with new technology acting as a new writing system, which is 
the target of literacy education. Multiliteracy theory argues that educating people to design a social future is the specific purpose of literacy. This theory uses the concept of design, which can be understood in terms of subjectivity, perceiving the social context, and designing it based on one's situation (Sang, 2017). The ability to use new technologies is an important aspect of multiliteracy. Literacy is an important and fundamental ability that can design the future. These facts reflect the continuous change in social competencies necessitated by the changing times.

Since 2012, the United Nations Educational, Scientific and Cultural Organization (UNESCO) has taken a new approach to literacy with the concept of future literacy (Miller, 2015). UNESCO (2021) defined future literacy as technology that allows people to better understand their future role in what they see and do, to strengthen their imagination, to improve their ability to prepare for change, to recover, and to invent. This definition implies that literacy is an individual ability to prepare for an uncertain future. People should have the ability to understand phenomena in the changing world. The competence they can acquire through literacy is anticipation. To anticipate, one needs to be able to understand social phenomena and analyze the impact on the future through an understanding of the present. This requires a comprehensive understanding of reading texts and civilization, which dominates social discourse beyond a critical understanding of the problems of society.

\section{Foundations of ai literacy}

Traditional literacy theory is the basis for establishing the concept of AI literacy. Literacy studies have transformed while contemplating the basic competencies that social participants require in order to respond to changes in society.

Literacy research has largely shifted from the individual cognitive to a social approach (MacGillivray \& Curwen, 2007). In addition, literacy has been viewed as a resource to maintain social relations (Barton \& Hamilton, 2000). The development of technology and its understanding have enabled social participation and communication. Therefore, technology literacy has developed into computer and ICT literacy with the aim of fostering individual abilities to use technology for social communication and participation (Davies, 2011). To reflect this, literacy research added a social role to traditional literacy, and the essential perspectives of various media have been applied.

This flow of change in literacy research is related to literacy learning. To learn technical literacy, functional literacy learning is required, followed by social literacy learning. AI literacy involves the acquisition of learner competencies required in the AI era based on learning functional, social, and technical literacy (Figure 1). 


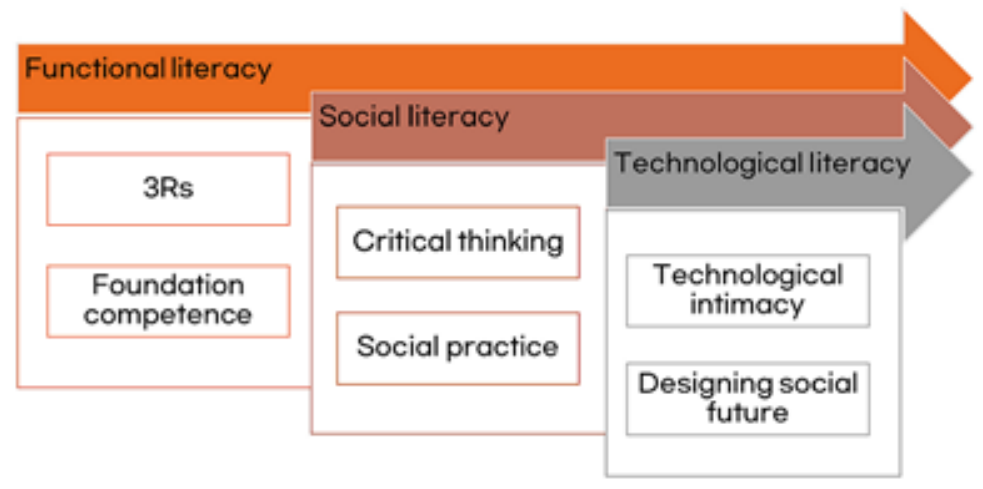

Al literacy

Figure 1. Foundation of AI literacy

As functional, social, and technological literacy underlie AI literacy, it is necessary to understand what they entail. Functional literacy marks the beginning of literacy and involves the learning of reading, writing, and arithmetic. It is the primary target of education, as acquiring letters, the basic symbols for communication, is the most important ability required to engage in society. UNESCO (2021) reported that at least 750 million people worldwide cannot read and write, and that 250 million children do not have basic literacy skills. Efforts are being made to combat this situation, as it causes unequal opportunities in social participation. Literacy is not a simple function but an essential skill for participation in society.

According to Taber (1987), functional literacy starts with the ability to decipher the text, that is, knowing the letters functionally, while understanding at the social level involves comprehending the social meaning of a text. Functional literacy further expands to include the ability to understand complex sentences, history, science, and technology. It refers to the overall ability to communicate socially through letters. This definition explains why reading is the beginning of literacy. Deciphering letters and understanding the meaning of symbols constitute the act of reading a text. Therefore, reading is the basis for learning and an important competency in education. In the 1970s, "reading" was replaced by "literacy" and began disappearing from educational terminology (Lankshear \& Knobel, 2007). Explaining the practical social properties of literacy is challenging with the concept of reading, and reading has begun to emphasize the conceptualization of worlds rather than simply reading text. Ultimately, traditional literacy aimed to facilitate learning of the social communication system of symbols by emphasizing the ability to read the text and to create a foundation for social communication by eradicating illiteracy. This was a core educational goal, as it was a fundamental element of social competence. 
As society grew more complex, reading began to demand the ability to understand society beyond merely deciphering the text. Social literacy began with a critical understanding of social phenomena. Street $(1997 \mathrm{a}, 1997 \mathrm{~b})$ focused on the social and cultural consciousness derived from reading and writing text and proposed that language be understood as an ability to promote social practice, referring to this as social literacy to emphasize the social nature and practices inherent in literacy itself. While traditional literacy indicates the ability to read and write without judging the value of a text, social literacy refers to the ability to use language to determine the value and create new perspectives. Social nature refers to the context specificity of social literacy. It is the ability to use practical language formed on the basis of the values and ideas of a social and cultural community and thus the ability to exert power in a specific context in society. Therefore, social literacy is inherently established within a certain period and society. Social nature and critical thinking are important for social literacy. The focus of discussions on language and literacy has shifted from the universal ability of language to social ability, as reported by Fairclough (2001), who discussed the approach of critically engaging with the context of a text to understand the social implications of language.

The importance of cultivating social participation and critical thinking skills through letter literacy can be extended through the ability to use communication media. Information is no longer communicated exclusively through text but devices such as computers and mobile phones. Thus, in modern society, the ability to use technology has become a basic ability required for communication. This perspective initiated research on technology literacy. Technology literacy is similar to digital literacy, which was introduced by Gilster (1997, p. 6) as "the ability to understand and use information in a variety of different formats created through computers". The emergence of various forms of digital and technology media have created various concepts of literacy, such as ICT, information, and computer literacy, which are encompassed by digital literacy. This is largely a category of technical literacy. According to the National Research Council (2002), various types of technology literacy are required to be technically literate for the society and era, including three independent characteristics: knowledge, way of thinking and acting, and ability. In other words, technology literacy implies that understanding the technology required by each era is essential. Technology intimacy is crucial to cultivate basic skills for technology use. Technology literacy and competence acquired based on technical intimacy help design a subjective life by adapting to the changes of the times. The ultimate purpose of literacy education is to provide subjectivity in life by increasing awareness of the basic media that lead society.

The three categories of literacy theories discussed above form the basis of AI literacy. Functional literacy is the foundation of a technical understanding of AI, while social 
literacy leads to the ability to think critically in the AI era. AI technology intimacy is the foundation of the ability to design one's future using AI technology.

\section{Ai era and ai literacy}

People are highly interested in the AI era. AI not only causes radical and unprecedented changes in the way people live and work, but also initiates greater changes in the future (Pan, 2016). AI rejects the idea that "humans only communicate with humans" providing opportunities for humans to talk to machines. In addition, AI technology gives rise to new social problems such as deepfake, data bias, digital privacy, and security (Kong et al., 2021). These changes in a new society require new learning, as people cannot understand and adapt to the changes without understanding the technologies and phenomena that have led to them.

Literacy has developed as a basic social ability for individuals to understand the society they live in. It has helped individuals to identify the essential abilities of the era and help them learn from the members of society. While the ability to read and write was a basic social competency in the era of letters, the ability to use computers happens to be a basic competency in the era of computer development. Functional literacy and computer literacy have been studied from this perspective. Modern AI society follows the same pattern, and AI literacy being investigated as a basic competency required in the era of AI.

Definitions of AI literacy are currently lacking, as AI literacy is included in extended digital literacy or data literacy discussions. AI literacy is related to other literacies. Digital literacy is a prerequisite for AI literacy; however, computational literacy is not necessarily a prerequisite for AI literacy. Data literacy is closely related to the AI subfield of machine learning, thus, certain data literacy competencies overlap with AI literacy competencies (Long \& Magerko, 2020, p. 2). In addition, the specific competencies required by the AI era are unclear. AI literacy, which requires further discussion, was found to have significant implications by Long and Magerko (2020). They defined AI literacy as an individual's ability to critically evaluate, use, and effectively communicate with AI. Aoun (2017) defined AI literacy as the ability to realize and utilize AI by understanding its concepts and usage. Wong, Ma, Dillenbourg and Huan. (2020) perceived AI concepts, applications, ethics, and safety as sub-elements of AI literacy. In other words, all definitions of AI literacy are based on setting goals for artificial intelligence education. Based on the research on artificial intelligence education and literacy, this study attempts to define AI literacy as follows. 
"AI literacy is an individual's ability to not only utilize AI, but to also critically recognize changing cultures. Furthermore, based on the basis of understanding AI, AI literacy allows the individual to design their own life. In other words, AI literacy is the basic ability to become a subjective human in the AI era."

AI literacy includes the passive ability to successfully protect personal information and the active ability to socially realize one's dream (goal) by appropriately utilizing AI (Kong et al., 2021).

AI literacy definition refers to an important competency to become a citizen who is not alienated from a changing society due to AI. A lack of AI literacy capabilities causes the problem of "digital divide and digital exclusion" among the members of society. Discussions on the digital divide began in the mid-1990s. The ability to use digital technology is important in the 21 st century, as the digital divide is related to information inequality and digital expansion causes political and social problems (Selwyn, 2004). In other words, the ability to use ICT is a prerequisite for a modern human being and citizen in this information age (Wills, 1999). The digital divide problem caused by the development of ICT is similar in the case of the AI technology era as well, including social problems, such as the inability to find jobs, and personal problems, such as the difficulty to use voice recognition devices. In addition, political biases caused by the exposure to biased Internet sources and fake news may cause problems with non-subjective rights in the use of information. Furthermore, virtual worlds, such as "metaverse", may cause perceptual problems in the expanded virtual world and the present world. Such problems in the AI era is related to the realization of human needs for expansion and human adaptation.

Are we good enough? If not, how can we improve ourselves? Must we restrict ourselves to traditional methods, such as studying and training, or should we also use science to directly enhance some of our mental and physical capacities (Savulescu \& Bostrom, 2009, p. 1)

Bostrom's discussion of human enhancement means that the human need for expansion are an instinct. As Maslow (1943) argued, humans basically have the need to belong to society, and belonging needs are an attempt to expand their abilities through others. Humans' instinctive need for belongingness and relationships could be expanded more widely in modern societies through the help of technology. Simondon's discussion (as cited in Kim, 2017) of the "relationship" between technology and humans as coexistence or the ANT theory (actor-network theory) represented by Latour (1996) represent a new perspective on the relationship between humans and technology. Considering Simondon's and Latour's discussions in terms of human expansion, it can be said that humans realize their need to expand via connections with technology. 
AI literacy aims to educate people living in the technological era to perceive objectively the technology they use. In fact, humans are very closely related to technology to realize their needs, and they are not aware of the impact of technology on them. Modern people not only connect to people or characters in the media, starting from a young age, but also connect with friends or family via the use of phones or computers. Since the development of AI technology, humans no longer use machines as mediators, they are directly connected to machines. Voice agent systems, such as Siri, are rudimentary machines that communicate directly with humans. This aspect of modern society shows that machines occupy an important position in human relationships. However, we are unaware of this.

While Turkle (2011) argues that advances in technology are making humans lonely, Tapscott (2008) argues that advances in technology are playing a role in narrowing the generational gap and increasing intimacy between them. These conflicting views are the same in that they argue that technology has a profound influence on human thinking and life patterns. The discussion of all artificial intelligence eras means that it is important for people living in this era to know what "artificial intelligence" is. To become a subjective human being who is not subordinate to anything, it is important to know exactly what affects an individual's life. As such, AI literacy is needed to be aware of the AI technology in use in the current AI era and to realize the impact of AI on our lives.

Technology itself carries no meaning, but it causes political, social, and personal problems depending on how humans use it. The AI world is with us today and in the near future. To ensure independent individual rights in the AI society, individuals must understand the social implications of technology, basic knowledge, and the ability to use technology. Thus, AI literacy is an essential ability in the AI era.

\section{Competence and purpose of ai literacy}

This study defined AI literacy as the basic ability to become an independent citizen in the AI era. Specific capabilities and purposes of AI literacy are discussed below, as setting the capabilities and objectives of literacy is not only a task of confirming the essential meaning of AI literacy but also a basis for constructing specific educational goals and contents.

AI literacy is continuous with previous forms of literacy (functional literacy, social literacy, technology literacy). Social literacy is necessary after the acquisition of functional literacy. Technology literacy emerged as technological competence was required to correspond with technological developments. Therefore, AI literacy includes abilities required to advance in the AI era after acquiring the reading, 
writing, and arithmetic skills, the social ability to critically understand society, and the technological ability to flexibly adapt to technological changes.

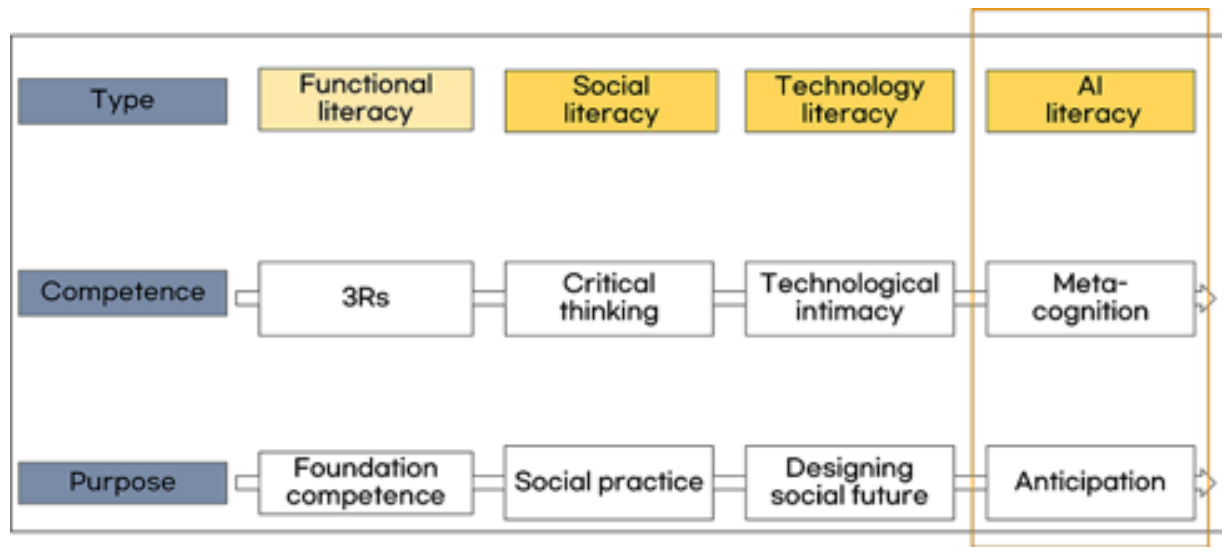

Figure 2. Competence and purpose of AI literacy

In addition, the purpose of AI literacy is related to previous literacy forms and based on functional, social, and technology literacy. AI literacy aims to anticipate its future and that of society based on basic competencies, social practices, and future social design. AI literacy is based on UNESCO's Futures Literacy (FL) and the Organization for Economic Co-operation and Development (OECD) Education 2030, which established educational goals for the $21^{\text {st }}$ century. On the basis of FL and Education 2030, the competencies required for $21^{\text {st }}$-century learners living in the AI era and the corresponding educational goals are metacognition and anticipation. Following FL and Education 2030, AI literacy refers to having the basic abilities required to live in the AI era without being limited to literacy skills using AI alone. The AI era differs from the previous era in that it is characterized by uncertainty and rapid change; however, data and technology development enables anticipation for the future. Anticipation is the subjective act of extending one's schema using technology, requiring metacognition for learning. Accordingly, the purpose and competence of AI literacy are anticipation and metacognition.

Metacognition is an important competence in AI literacy, which refers to "thinking about thinking" (Livingston, 2003, p. 2). However, defining it is not easy. The term metacognition is most often associated with Flavell (1979), who stated that metacognition consists of both metacognitive knowledge and metacognitive experiences or regulation. Metacognitive knowledge refers to acquired knowledge about cognitive processes, which can be used to control cognitive processes (Livingston, 2003). Metacognition is relevant in various forms of self-control and 
self-instruction, and it has been used in various fields, such as social learning theory and education (Flavell, 1979). Nonetheless, the concept of metacognition remains unclear, despite continuing research. Wellman (1985, as cited in Zemira \& Bracha, 2014) identified many thought processes with no clear commonality that were connected and referred to as metacognition. Yussen (1985) argued that this is due to scholars generally adopting an open definition method that presents a few typical examples to supplement the concept after making a rough definition of it. Flavell (1979) contrasted cognition and metacognition to correct the original concept, where cognition is an intellectual activity for cognitive process, while metacognition functions to check cognitive activity through the recognition of these cognitive activities. Flavell (1979) explained that metacognition develops as children acquire the ability to distinguish between practical and inaccurate or fantastic understandings after undertaking learning processes in situations in which they were unable to distinguish between what they knew and did not know. Metacognition is one of the competencies (skills) in the learning compass of Learning Framework 2030. Metacognition is considered important for future education because, subjectivity in learning is important given the the diversity of knowledge. Knowing what one needs to know, what information to access, whom to talk to, and how to network in designing one's future are important for the present and the future. In traditional educational societies, following standardized social frameworks and education and learning standards has ensured a successful future for individuals. However, in the volatile and uncertain of the future society, such standards are not available. For future societies, represented by volatility, uncertainty, complexity, and ambiguity (VUCA), learners must establish their own learning methods and standards. The metacognitive ability to know exactly what one knows and needs to learn is essential to achieving the goal. Through metacognitive ability, learners can enjoy the subjectivity of learning, engage in creative learning in various forms, and design various futures. In the AI era, learners should determine and design using meta-information to check the quality of the learning data provided through a customized learning system centered on learners rather than instructors. Thus, metacognition is an important competence in the era of AI, as it aims to strengthen self-learning.

The purpose of cultivating AI literacy is anticipation. The OECD Learning Framework 2030 (as cited in Taguma, Feron, and Lim, 2018) noted that the learning environment is becoming VUCA while presenting a vision for future education and stated that common understanding and effort are required to create resilient societies and promote innovation, growth, and development. In this environment, the outcome of life varies depending on how learners adapt to changes in society (Howells, 2018). AI literacy is an essential ability for future talent to explore uncertain and complex societies, predict future problems, and find solutions. Taking a critical position for 
decisions and actions by understanding and reflecting on social issues is important as it can facilitate inclusiveness and accommodate multiple perspectives. Educating people to design their future lives considering potential future requirements and the effect of actions taken today on the future is an important factor in educating responsible and subjective humans (Howells, 2018). Anticipation, the purpose of AI literacy, includes the importance of digital literacy and the ability to interact with various cultures through the core competencies of education presented by the DeSeCo project. In addition, anticipation can be understood in combination with the advanced concept of transformative competencies presented in Education 2030. Transformative competencies are explained in connection with student agency (Howells, 2018). They allow for a personalized learning environment where each student creates motivation for learning, links it to other learning experiences, and collaborates with other students to design their own learning processes. The technological competence developed through this process can enable learners to collect and analyze data based on their abilities. Learners no longer learn and assess within a fixed educational program but can design and learn the educational content they need by subjectively collecting and analyzing information. At a time when the teacher's role has changed from teaching to coaching, learners need to cultivate subjectivity. With the knowledge gained through subjective learning, people should design their future by analyzing and anticipating an uncertain reality and be prepared to exert influence by anticipating change.

According to Miller (2018), the future is a prediction made in the present. Factors that determine the future depend on how one analyzes the present and its implications for the future. The ability to anticipate the future is not only meaningful at the level of an individual's life but also important at the environmental level for a sustainable planet. In the AI era, technology enables envisioning the future through the present. Therefore, by anticipating the future of oneself, society, and the planet through the present, efforts can be made to achieve wellbeing, which was presented as the goal in the OECD Learning Framework 2030.

\section{Conclusion}

Literacy education aims to cultivate the basic skills for free life. It is necessary to avoid unequal access to information and be able to participate as an important member of society. The ability to understand and criticize society are essential. As technology became an important medium for communication, it also became an important object of literacy. 
Modern society is foreshadowing a new world, unlike the previous framework. Beyond the ability to read and write, literacy now implies the ability to network and contact wider circles with greater information. Education places a greater focus on the learner's frame than the teacher's. AI lies at the center of this change. AI is no longer a technology only for experts but has become an object of everyday life that exists and daily experiences. Like writing, AI has entered everyday life and become a target of basic literacy. AI literacy is based on competencies and purpose targeted by existing literacy education. It starts with understanding the characteristics of AI and the society to which it is applied, followed by considering the competencies and educational purposes that learners who will live in the future should have. AI helps humans expand information and relationships. However, to obtain the benefits provided by AI technology, appropriate education in obtaining the desired information is required. This learning is subjective learning led by learners rather than instructors. Metacognition, which is crucial for subjective learning, was established as the competence of AI literacy. The purpose of AI literacy education through cultivating metacognitive competence is to anticipate the future. Learners in the AI era must possess this ability, including an understanding of the characteristics of AI technology and considering the characteristics of an uncertain and ambiguous future society.

The competence and purpose of AI literacy suggested in this paper form the foundation for a discussion of AI literacy. Along with efforts to define the AI era, future discussions should focus on specific educational content. However, basic discussions such as this one should be actively conducted to identify educational topics because, the educational content of the AI era can be materialized through an understanding of what the present time requires and how it will affect the future.

Acknowledgments: This work was supported by the Ministry of Education of the Republic of Korea and the National Research Foundation of Korea (NRF-2017S1A 6A 3A 01078538).

\section{References}

Aoun, J. E. (2017). ROBOT-PROOF: Higher education in the age of artificial intelligence. Cambridge, MA: MIT Press.

Barton, D. \& Hamilton, M. (2000). Literacy practices. In D. Barton, M. Hamilton \& R. Ivanic (Eds.), Situated literacies: Reading and writing in context (pp. 7-15). London: Routledge.

Barton, D. (2001). Directions for literacy research: Analysing language and social practices in a textually mediated world. Language and education, 15(2-3), 92-104.

Bradent, R. A. \& Hortinf, J. A. (1982). Identifying the theoretical foundations of visual literacy. Journal of Visual Verbal Languaging, 2(2), 37-42. 
Burnett, C. \& Merchant, G. (2020). Literacy-as-event: Accounting for relationality in literacy research. Discourse: Studies in the cultural politics of education, 41(1), 45-56.

Chrisomalis, S. (2009). The origins and coevolution of literacy and numeracy. In The Cambridge handbook of literacy, 59-74.

Davies, R. S. (2011). Understanding technology literacy: A framework for evaluating educational technology integration. TechTrends, 55(5), 45-52.

Debes, J. (1968). Some foundations for visual literacy. Audiovisual Instruction, 13, 961-964.

Debes, J. (1969). The loom of visual literacy: an overview, Audiovisual Instruction, 14(8), 25-27.

Fairclough, N. (2001). Language and power. Pearson Education.

Flavell, J. H. (1979). Metacognition and cognitive monitoring: A new area of cognitive-developmental inquiry. American psychologist, 34(10), 906-911.

Gee, J. (1990). Social Linguistics and Literacies (2nd ed.). London: Falmer Press.

Gee, J. (2005). The new literacy studies: From 'socially situated' to the work. Situated literacies: Reading and writing in context, 2, 177-194.

Gilster, P. \& (1997). Digital literacy. New York: Wiley Computer Pub.

Hahn, J. S. (2000). New Interpretation and New Approaches to Media Educcation: Integrated Multiliteracies. Journal of Educational Technology, 16(2), 167-169.

Hall, N. (1987). The emergence of literacy. Portsmouth: Heinemann Educational Books Inc.

Heath, S. B. (1982). What no bedtime story means: Narrative skills at home and school. Language in Society, 11(1), 49-76.

Holdaway, D. (1984). Stability and change in literacy learning. Exeter, NH: Heinemann Educational Books.

Horton Jr, F. W. (1983). Information literacy vs. computer literacy. Bulletin of the American Society for Information Science, 9(4), 14-16.

Howells, K. (2018). The future of education and skills: education 2030: the future we want, https://www. oecd.org/education/2030/E2030\%20Position\%20Paper\%20(05.04.2018).pdf

Johnson, B. D. (1977). Visual literacy, media literacy and mass communications for English instruction. Northwestern University.

Kagitcibasi, C., Goksen, F. \& Gulgoz, S. (2005). Functional adult literacy and empowerment of women: Impact of a functional literacy program in Turkey. Journal of adolescent \& adult literacy, 48(6), 472 489.

Kim, J. H. (2017). Simondon's philosophy of technology. Seoul: Acanet.

Kong, S. C., Cheung, W. M. Y. \& Zhang, G. (2021). Evaluation of an artificial intelligence literacy course for university students with diverse study backgrounds. Computers and Education: Artificial Intelligence, 100026 .

Lankshear, C. \& Knobel, M. (2007). Sampling "the new" in new literacies. A new literacies sampler, 29, $1-24$.

Latour, B. (1996). On actor-network theory: A few clarifications. Soziale welt, 369-381.

Livingston, J. A. (2003). Metacognition: An Overview, https://files.eric.ed.gov/ fulltext/ED474273.pdf

Long, D. \& Magerko, B. (2020, April). What is AI literacy? Competencies and design considerations. In Proceedings of the 2020 CHI Conference on Human Factors in Computing Systems (pp. 1-16).

Luehrmann, A. \& Peckham, H. D. (1983). Computer Literacy; A Hands on Approach. McGraw-Hill, Inc.

MacGillivray, L. \& Curwen, M. S. (2007). Tagging as a social literacy practice. Journal of Adolescent \& Adult Literacy, 50(5), 354-369.

Maslow, A. H. (1943). A theory of human motivation. Psychological review, 50(4), 370.

Miller, R. (2018). Futures Literacy: transforming the future. In Transforming the future. Anticipation in the 21 st century (pp. 1-12). London, New York: Routledge Taylor \& Francis Group. 
Nichols, S. (2007). Children as citizens: literacies for social participation. Early Years, 27(2), 119-130.

OECD (2005). The definition and selection of key competencies: Executive summary. Paris: OECD.

Pan, Y. (2016). Heading toward artificial intelligence 2.0. Engineering, 2(4), 409-413.

Salomon, G. (1982). Television literacy and television vs. literacy. Journal of Visual Verbal Languaging, 2(2), 7-16.

Sang, Y. (2017). Expanded Territories of "Literacy": New Literacies and Multiliteracies. Journal of Education and Practice, 8(8), 16-19.

Savulescu, J. \& Bostrom, N. (Eds.). (2009). Human enhancement. OUP Oxford.

Selwyn, N. (2004). Reconsidering political and popular understandings of the digital divide. New media \& society, 6(3), 341-362.

Street, B. V. (1997a). The implications of the 'New Literacy Studies' for literacy education. English in education, 31(3), 45-59.

Street, B. V. (1997b). Social literacies. In Encyclopedia of language and education, 133-141.

Street, B. V. (1998). New literacies in theory and practice: What are the implications for education? Linguistics and Education, 10,1-24.

Street, B. V. (2003). What's "new" in New Literacy Studies? Critical approaches to literacy in theory and practice. Current issues in comparative education, 5(2), 77-91.

Taber, S. R. (1987). ERIC/RCS: Current Definitions of Literacy. Journal of Reading, 30(5), 458-461.

Taguma, M., Feron, E. \& Lim, M. H. (2018). Education and AI: preparing for the future \& AI, Attitudes and Values, https://www.oecd.org/education/2030/Education-and-AI-preparing-for-the-future-AIAttitudes-and-Values.pdf

Tapscott, D. (2008). Grown up digital. Boston: McGraw-Hill Education.

The National Research Council (2002). Technically speaking: Why all Americans need to know more about technology. National Academies Press.

The New London Group (1996). A pedagogy of multiliteracies: Designing social futures. Harvard educational review, 66(1), 60-93.

Turkle, S. (2011). Alone together: Why we expect more from technology and less from each other. New York: Basic Books.

UNESCO (2021, January 30). Futures Literacy. An essential competency for the 21st century, https:// en.unesco.org/futuresliteracy/about

UNESCO (2021, January 30). Literacy, https://en.unesco.org/themes/literacy

Watzlawick, P., Bavelas, J. B. \& Jackson, D. D. (2011). Pragmatics of human communication: A study of interactional patterns, pathologies and paradoxes. WW. Norton \& Company.

Wills, M. (1999). Bridging the Digital Divide. Adults Learning, 10-11.

Wong, G., Ma, X., Dillenbourg, P. \& Huan, J. (2020). Broadening artificial intelligence education in K-12: where to start? ACM Inroads, 11(1), 20-29.

Yussen, S. R. (1985). The role of metacognition in contemporary theories of cognitive development. Contemporary Research in Cognition and Metacognition.

Zemira, M. \& Bracha, K. (2014). Educational Research and Innovation Critical Maths for Innovative Societies The Role of Metacognitive Pedagogies: The Role of Metacognitive Pedagogies. OECD publishing. 


\section{Uspostavljanje koncepta UI pismenosti: Fokusiranje na kompetenciju i svrhu}

\section{SAŽETAK}

Ova istraživanje imalo je za cilj ispitati koncept, kompetenciju i obrazovne ciljeve pismenosti umjetne inteligencije (UI) kako bi se istražile osnovne kompetencije potrebne za život u eri umjetne inteligencije. Suvremeno društvo nagovještava novi svijet, za razliku od prethodnog poretka. Osim sposobnosti čitanja i pisanja, pismenost sada podrazumijeva i sposobnost umrežavanja i kontakta sa širim krugovima s opširnijim informacijama. Okvir učenika dobio je veću važnost od okvira učitelja u obrazovanju. UI ima središnju ulogu u donošenju ovih promjena. Kao i pisanje, UI je ušao u sustav svakodnevnog života i postao meta u osnovnoj pismenosti. Ovo istraživanje istraživalo je koncept i karakteristike pismenosti UI-ja. UI pridonosi poboljšanju ljudskih sposobnosti širenjem ljudskih odnosa i opsega stjecanja informacija. Međutim, ove karakteristike umjetne inteligencije zahtijevaju od ljudi da samostalno biraju što trebaju znati is kim će se povezati. Znati što treba znati je metakognicija. Stoga ovo istraživanje razmatra metakogniciju kao kompetenciju pismenosti UI-ja. Osim toga, pokušaj stjecanja točnijeg znanja putem metakognicije predstavlja nastojanje da se predvidi neizvjesna budućnost. Stoga je svrha pismenosti UI-ja imati sposobnosti predviđanja.

Ključne riječi: pismenost, pismenost UI-ja, kompetencija pismenosti UI-ja, svrha pismenosti UI-ja, metakognicija, predviđanje. 